\title{
Original Research \\ Hydroclimatic Trends in Areas with High Agricultural Productivity in Northern Mexico
}

\author{
Omar Llanes Cárdenas ${ }^{1}$, Mariano Norzagaray Campos ${ }^{1}$, Norma Patricia Muñoz Sevilla ${ }^{2}$, \\ Rosario Ruiz Guerrero ${ }^{3}$, Enrique Troyo Diéguez ${ }^{4 *}$, Píndaro Álvarez Ruiz ${ }^{1}$ \\ 'Interdisciplinary Research Center for Integrated Regional Development, National Polytechnic Institute, \\ Sinaloa Unit, Mexico \\ ${ }^{2}$ Department of Research and Graduate Studies, National Polytechnic Institute, D.F., Mexico \\ ${ }^{3}$ Center for Technological Innovation and Research, National Polytechnical Institute, \\ Cerrada de Cecati S/N, Col. Santa Catarina, Azcapotzalco D.F., Mexico \\ ${ }^{4}$ Northeastern Center for Biological Research, Playa Palo de Santa Rita Sur 195; La Paz, B.C.S. México
}

Received: 21 July 2014

Accepted: 23 September 2014

\begin{abstract}
Global climate change affects not only temperature but also the hydrologic cycle and therefore the aridity index, with variations at the local level. A non-parametric analysis was carried out on time series data collected from temperature and precipitation records (1970 to 2011) from 38 CONAGUA (National Water Commission) weather stations located in the Mexican states of Sinaloa, Baja California Sur, Durango, Sonora, and Chihuahua. The magnitude of change trends of average, maximum, and minimum temperature and precipitation, potential evapotranspiration, and the aridity index were calculated. The data were aggregated, and the Mann-Kendall statistic calculated using the MOCLIC 1.0 program, to determine whether there was continuity in the data from each station and to define the magnitude of the statistically significant trend under the threshold $\alpha=0.05$. The magnitude of the change trend was determined for significant trends using Sen's method of slopes. Potential evapotranspiration and the aridity index were calculated by the Hargreaves and UNEP methods. The results show that the climate variables displayed positive and negative trends; mainly temperature, with a range of -0.13 to $0.16^{\circ} \mathrm{C} \cdot \mathrm{yr}^{-1}$, which is above world averages. The values obtained for RMSE, bias, the Pearson correlation coefficient $(\mathrm{r})$ and the coefficient of determination $\left(\mathrm{R}^{2}\right)$ do not show significant differences between the control values and the calculated values. It was concluded that aggregating significant trends can provide information on the direction of local climate change in this environment in northern Mexico, and its important consequences and repercussions, as well as impacts on social and environmental systems.
\end{abstract}

Keywords: aridity index, significant, non-parametric analysis

\section{Introduction}

Significant trends (ST) in factors that define climate change indicate modifications in average air temperature $\left(\bar{T}_{\text {avg }}\right)$, which in turn are related to global warming and may

*e-mail: etroyo04@ cibnor.mx trigger a change in global climate patterns. Projections made by the Intergovernmental Panel on Climate Change (IPCC) estimate that by $2100, \bar{T}_{\text {avg }}$ could increase by 1.8 to $4^{\circ} \mathrm{C}$, which may affect the variability of the global climate and, in turn, the ST of maximum temperature $\left(\bar{T}_{\text {max }}\right), \bar{T}_{a v g}$, and minimum temperature $\left(\bar{T}_{\text {min }}\right)$ [1]. These shifts could cause further changes, which are usually reflected in aver- 
age annual rainfall $(\bar{P})$, altering the hydrologic cycle and thereby changing local climates. Related to this, in the last three decades of the previous century, an increase in $\bar{T}_{\text {avg }}$ of about $0.15^{\circ} \mathrm{C}$ decade $^{-1}$ has been documented [2]. To analyze environmental temperature changes more thoroughly, an $S T$ can be divided into a positive trend $(P T)$ and a negative trend $(N T)$; where a $P T$ means an increase in the parameter of interest and $N T$ a decrease [3]. For example, a $P T$ in $\bar{T}_{\max }$, $\bar{T}_{\text {avg }}$, and $\bar{T}_{\text {min }}$ indicate warming in some particular region; an $N T$ of the same three parameters indicates cooling (T). According to [4], $P T$ in the frequency of extreme events associated with $\bar{P}$ have been detected in various regions of the World. These variables are indicators of the absence or presence of different types of rainfall, heat waves and droughts, which can cause flooding, soil erosion, tornadoes, major hurricanes, and other extreme weather events that have been causing both natural and human disasters in various parts of the World, especially in coastal areas [5].

According to [6], the effects of climate change are more pronounced in developing countries such as Mexico, where atypical and extraordinary climate events have been occurring in recent years, such as freezes, drought, increased river flooding, extreme siltation, severe hurricanes, landslides, and more - climate events that trigger starvation, poverty, and unemployment. These phenomena have been reported by the agricultural industry in the states of Sinaloa (SIN), Baja California Sur (BCS), Durango (DGO), Chihuahua (CHI), and Sonora (SON) in northwest Mexico. In spite of the availability of global and regional climate models, which may provide important input for decision makers working to counteract the effects of climate change, this information is not very representative of climate change effects on a local scale that could be used for timely decision-making. Motivated by the importance of the issue, the aim of this study was to determine the current state of the local climate, primarily by identifying climate change indicators and then conducting a statistical analysis to quantify $S T$ of climate change. A time series of data from 38 CONAGUA weather stations in the five states of the region under study was used. In order to detect $S T$ in average monthly $T$ data and cumulative monthly $\bar{P}$ for the study period, average annual $T_{\max }, T_{\text {avg }}, T_{\min }$, and precipitation $(P)$ were calculated for each station, in addition to average potential evapotranspiration (PET) and aridity index (AI). PET was calculated by the method of [7] and $A I$ by the method of the United Nations Environment Program [8].

All variables were evaluated with a $95 \%$ confidence level, following the nonparametric methodology of MannKendall to find in which zones significant changes or $S T$ in the climate variables occurred and to generate hypotheses about threats to agricultural production associated with climate change in the study area. Thus, by estimating the magnitude of changes in the climate variables studied, a spatial map of changes in recent decades could be constructed. It should be noted that there are various methods for spatial interpolation of climate variables. These methods construct continuous equipotential climate surfaces based on recorded data [9]. In this study, the inverse distance weighting
(IDW) interpolation method was used. The justification for choice of the study region is that the state of SIN is where the Guasave Valley is located. This is the most important agricultural region of Mexico, commonly called the "agricultural heart of Mexico" and it must be protected to preserve Mexico's food sovereignty [10,11]. Moreover, the states of SIN and BCS contain numerous World-renowned tourist areas including Mazatlán, La Paz, Cabo San Lucas, and San Jose del Cabo, among others [12] - sources of foreign revenue and employment. Due to its climate and environmental richness, BCS is the Mexican state with the greatest number of wetlands - an important habitat to conserve. For the state of DGO, it was considered important to apply the methodology for several sound reasons, including the state's 12 wetlands, which are important for Mexico, and the fact that DGO has weather stations at the highest elevations $(E)$ of the states analyzed, resulting in different climate zones. Moreover, it has numerous agricultural, forestry, and drought problems. CHI was chosen because of its rich forest resources and because it has the highest $(E)$ of all the states analyzed here. SON is included in the study region for its large number of species of flora and fauna and, like SIN, for its agricultural production [13].

\section{Materials and Methods}

Thirty-eight CONAGUA (National Water Commission) weather stations in northern Mexico were analyzed for the period 1970-2011. Thirteen are located in SIN (population 2,767,761), 16 in BCS (population 637,026), six in DGO (population 1,632,934), two in CHI (population $3,406,465$ ), and one in SON (population 2,662,480) [14]. The E ranges (m a.s.l.) of weather stations in each state were: SIN 5 to 2,050, BCS 10 to 502, DGO 15 to 2,300, CHI 780 to 2,435, and SON 50. Except for DGO, the states are all connected to mountain regions (Sierra Madre Occidental) and the Gulf of California [15] (Fig. 1). Most of the time series had continuity problems such as missing data and outliers, so time series tools were used to fill in the data gaps. The methodologies used were Mann-Kendall statistics and Sen's slope estimation method, which are appropriate for data with outliers or highly skewed values, as was the case for $\bar{P}$ and $\bar{T}$, and have also been used to detect, estimate and quantify annual averages of trends in time series of atmospheric variables, and quality of water for human consumption, agricultural irrigation, and concentrations of atmospheric pollutants, among others $[16,17]$. To meet the goals of this study, $\bar{P}$ was taken at all weather stations to be a variable that decreases with $E$, from dry zones with values $<100 \mathrm{~mm}$ to humid zones with magnitudes $>1000$ (Table 1). According to [18], to analyze data from a thermopluviographic series for possible $S T$, the series must be the result of at least 30 years of monitoring. The CONAGUA data was therefore suitable for detecting the presence of $S T$. Annual time series were constructed for $T_{\max }, T_{\text {avg }}, T_{\min }$, PET, and $A I$; to calculate the averages of $\bar{T}_{\max }, \bar{T}_{\text {avg }}, \bar{T}_{\text {min }}$, $\overline{P E T}$, and $\overline{A I}$ and average annual cumulative $\bar{P}\left(\bar{P}_{a}\right)$. 


\section{Map A}

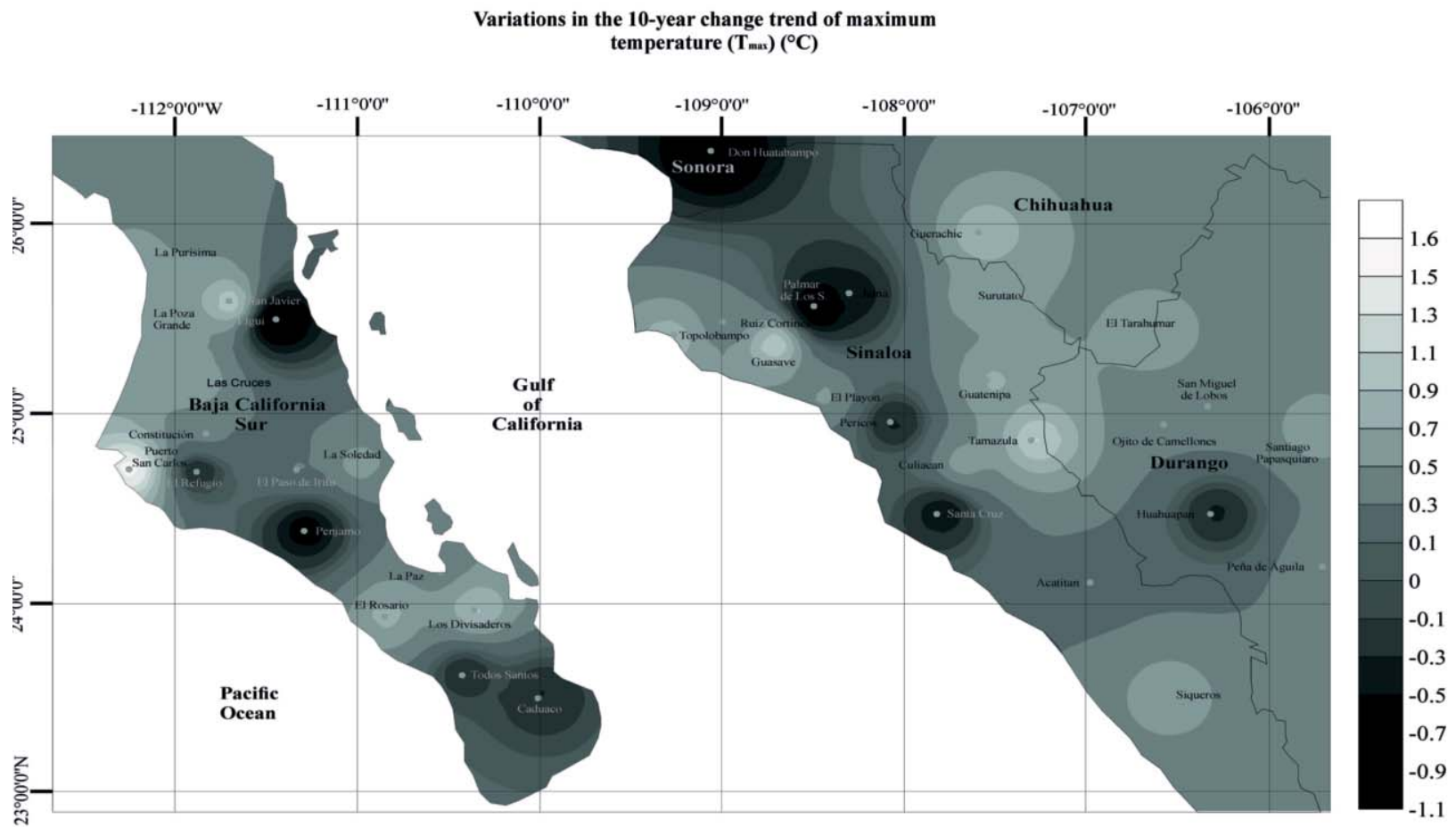

Variations in the 10-year change trend of maximum temperature $\left(\mathrm{T}_{\max }\right)\left({ }^{\circ} \mathrm{C}\right)$ by weather station
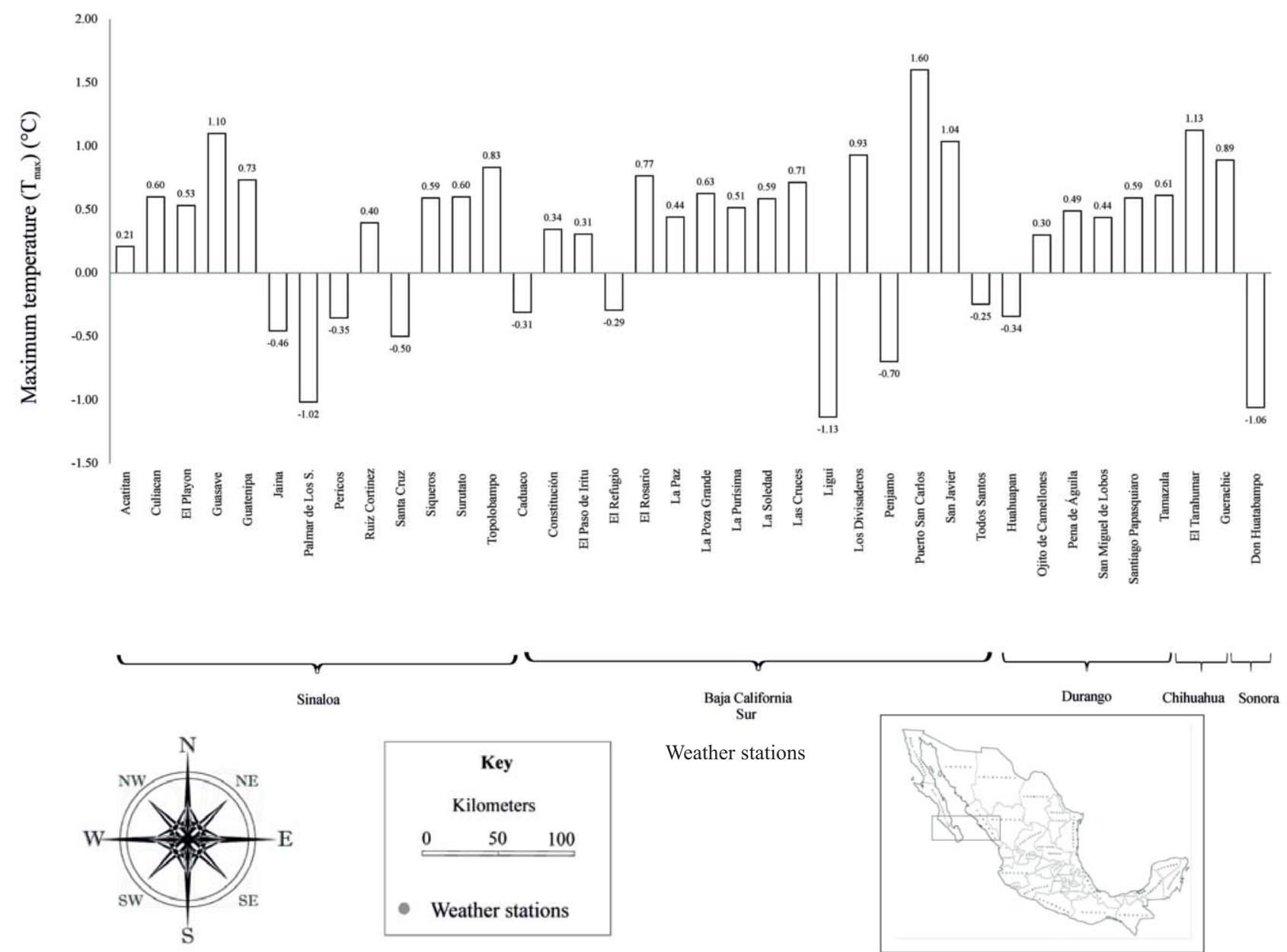

Fig. 1. Magnitude of the change trend in $T_{\max }$ (Map A), $T_{\text {min }}$ (Map B), and $T_{\text {avg }}$ (Map C) in states in northern Mexico with high agricultural productivity. 


\section{Map B}
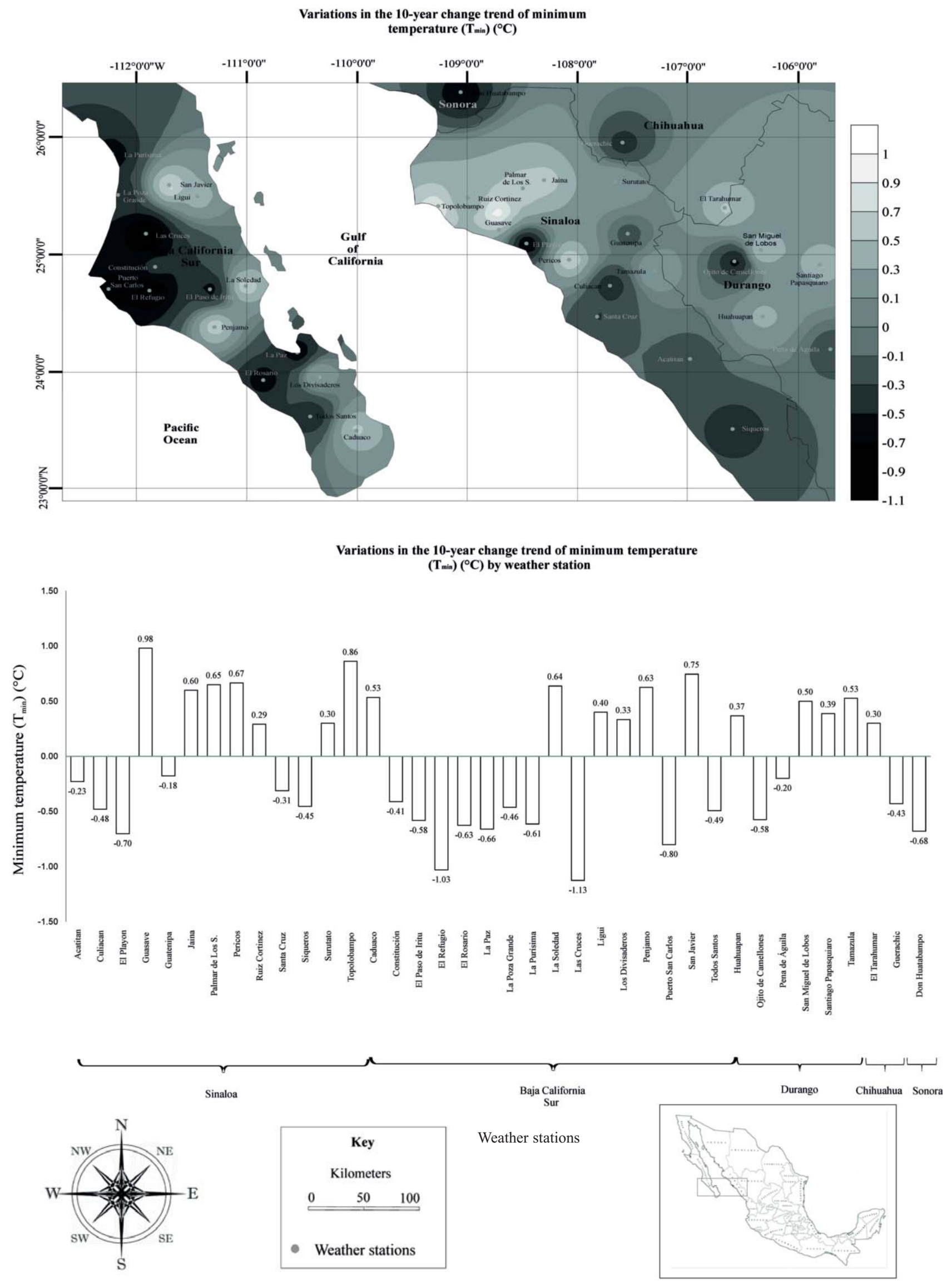

Fig. 1. Continued. 


\section{Map C}

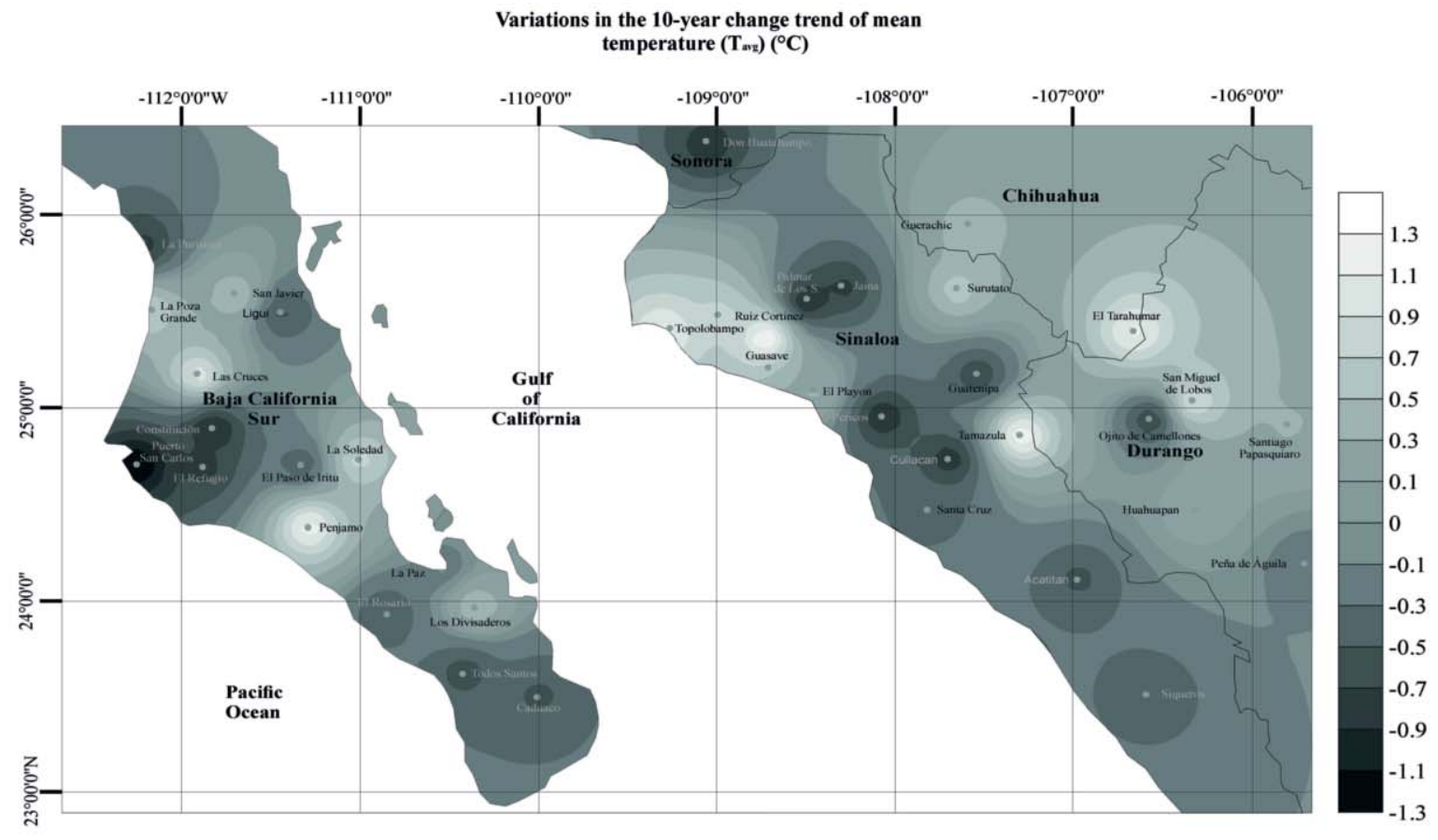

Variations in the 10-year change trend of mean temperature $\left(\mathrm{T}_{\mathrm{wz}}\right)\left({ }^{\circ} \mathrm{C}\right)$ by weather station

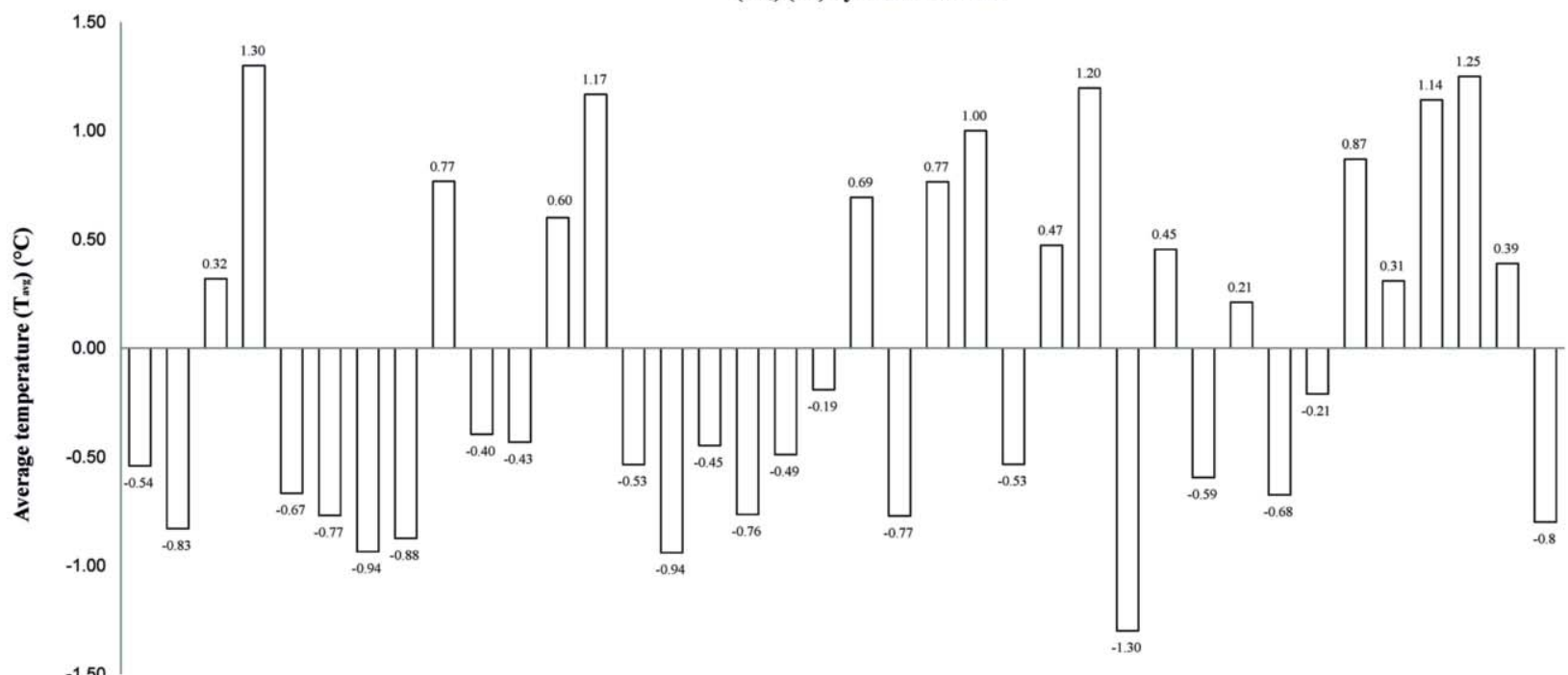

$-1.50$

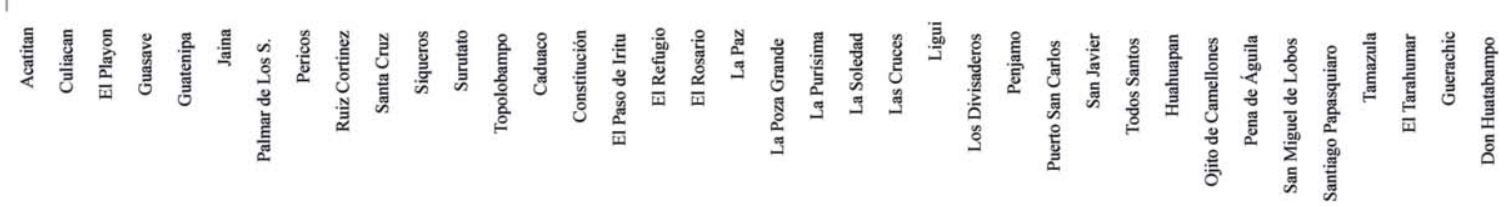
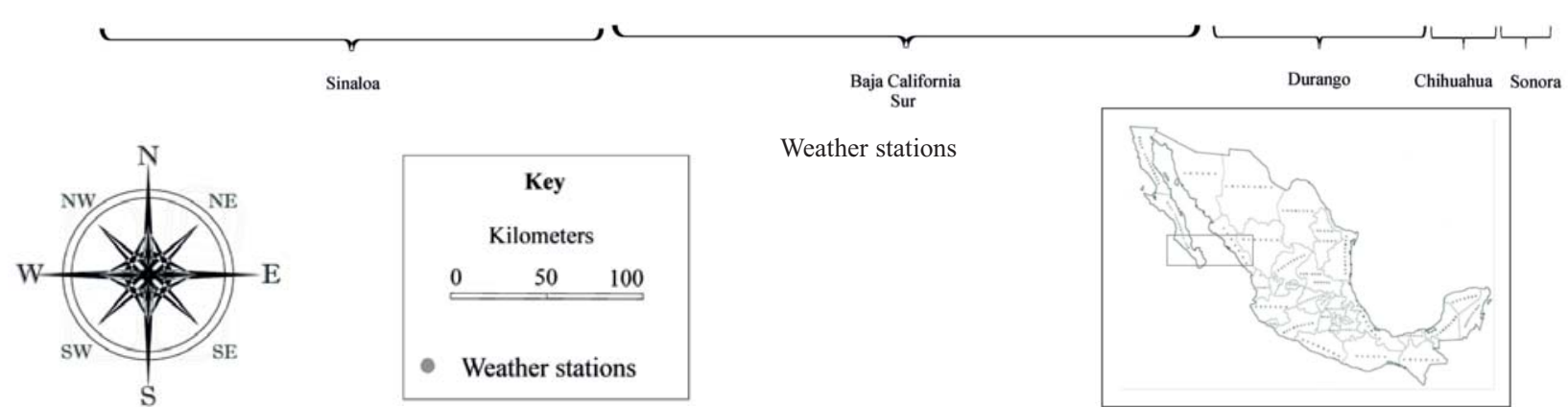

Weather stations

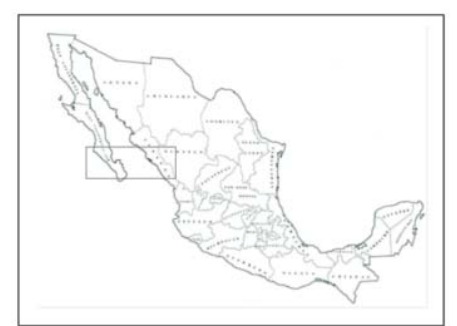

Fig. 1. Continued. 
Table 1. Trend indicators using the Mann-Kendall statistic.

\begin{tabular}{|c|c|c|c|c|c|c|c|c|c|}
\hline \multicolumn{4}{|c|}{ Location } & \multicolumn{6}{|c|}{ Standarized $\mathrm{Z}\left(\mathrm{Z}_{\text {std }}\right)$ with $\alpha=0.05$. threshold, $\mathrm{Z}=/ 1.96 /$ (Dimensionless) } \\
\hline State & Weather station & $E(\operatorname{mas})$ & $\bar{P}_{a}\left(\mathrm{~mm} \cdot \mathrm{yr}^{-1}\right)$ & $\bar{T}_{\max }$ & $\bar{T}_{\text {avg }}$ & $\bar{T}_{\min }$ & $\bar{P}$ & $\overline{P E T}$ & $\overline{A I}$ \\
\hline \multirow{13}{*}{ Sinaloa } & Acatitan & 130 & 806 & 0.58 & -6.33 & -0.78 & 0.63 & -5.22 & -0.38 \\
\hline & Culiacan & 40 & 712 & 2.82 & -1.75 & -0.59 & -0.93 & 0.04 & 0.21 \\
\hline & El Playon & 5 & 483 & 3.87 & 1.76 & -4.86 & -3.61 & 3.83 & 2.59 \\
\hline & Guasave & 40 & 461 & 2.83 & 2.01 & 3.35 & 0.97 & 1.51 & -1.2 \\
\hline & Guatenipa & 18 & 1017 & 3.01 & -6.3 & -4.47 & -0.6 & -0.3 & 0.86 \\
\hline & Jaina & 200 & 884 & -4.15 & -5.39 & 4.8 & -0.04 & -8.65 & 0.92 \\
\hline & Palmar de Los S. & 21 & 609 & -1.82 & -0.28 & 3.49 & -1.38 & -2.97 & 2.66 \\
\hline & Pericos & 11 & 685 & -0.56 & -2.24 & 0.49 & 1.56 & -3.32 & -0.41 \\
\hline & Ruiz Cortinez & 15 & 378 & 5.91 & 2.18 & 5.31 & 0.33 & -1.102 & -1.2 \\
\hline & Santa Cruz & 2050 & 763 & -0.39 & -6.18 & -2.58 & 0 & -4.94 & 0.1 \\
\hline & Siqueros & 12 & 709 & 1.8 & -3.82 & -1.52 & -0.303 & -1.63 & 1.67 \\
\hline & Surutato & 1400 & 1029 & 3.25 & 4.92 & 3.34 & 0.11 & 3.39 & -0.45 \\
\hline & Topolobampo & 34 & 310 & 0.42 & 1.24 & 4.34 & 1.19 & -0.96 & 1.05 \\
\hline \multirow{16}{*}{$\begin{array}{c}\text { Baja } \\
\text { California } \\
\text { Sur }\end{array}$} & Caduaco & 206 & 443 & -0.2 & -1.17 & 1.4 & 3.64 & -2.37 & -1.22 \\
\hline & Constitución & 47 & 168 & 5.28 & -3.81 & -1.04 & -0.31 & 1.22 & 0.88 \\
\hline & El Paso de Iritu & 135 & 199 & 3.38 & -2.27 & -7.42 & 1.84 & 5.21 & -0.33 \\
\hline & El Refugio & 23 & 91 & -0.68 & -3.35 & -3.27 & 3.75 & 1.23 & -4.5 \\
\hline & El Rosario & 45 & 109 & 3.88 & -1.32 & -1.13 & -0.86 & 2.71 & 0.42 \\
\hline & $\mathrm{LaPaz}$ & 16 & 176 & 5.63 & -3.64 & -2.73 & -0.18 & 6.21 & 1.47 \\
\hline & La Poza Grande & 25 & 64 & 4.06 & 3.73 & -3.34 & 1.33 & 6.68 & 0.93 \\
\hline & La Purísima & 95 & 115 & 2.35 & -3.89 & -3.05 & 0.64 & 0.1 & 0.06 \\
\hline & La Soledad & 412 & 272 & 2.06 & 0 & 0.42 & 1.86 & -0.28 & -0.62 \\
\hline & Las Cruces & 40 & 125 & 0.26 & 0.24 & -2.35 & 0.86 & 3.75 & 0.01 \\
\hline & Ligui & 10 & 218 & -2.5 & -2.74 & 1.87 & 0.95 & -2.28 & 1.11 \\
\hline & Los Divisaderos & 502 & 403 & 1.74 & 2.13 & 4.66 & 1.11 & -0.15 & 0.67 \\
\hline & Penjamo & 24 & 137 & -2.49 & 1.65 & 1.25 & -0.95 & -0.81 & 1.85 \\
\hline & Puerto San Carlos & 10 & 91 & 0.65 & -4.84 & -0.37 & 0.11 & -0.78 & 0.24 \\
\hline & San Javier & 440 & 301 & 4.65 & 1.18 & 3.42 & 0.79 & 3.58 & 2.69 \\
\hline & Todos Santos & 75 & 170 & -1.65 & -5.37 & -5.6 & 1.02 & -1.46 & 1.02 \\
\hline \multirow{6}{*}{ Durango } & Huahuapan & 1150 & 823 & -0.05 & 0.83 & 1.15 & 0.29 & 0.61 & -3.51 \\
\hline & Ojito de Camellones & 15 & 1530 & 0.95 & -3.44 & -1.73 & 1.72 & -2.35 & -2.3 \\
\hline & Pena de Águila & 1896 & 534 & 2.21 & -6.06 & -2.55 & 0.57 & -4.15 & 0.89 \\
\hline & San Miguel de Lobos & 2300 & 847 & 5.02 & 5.32 & 5.14 & -1.84 & 5.42 & -0.31 \\
\hline & Santiago Papasquiaro & 1716 & 505 & 0.68 & 3.74 & 1.96 & 4.25 & 2.82 & -0.07 \\
\hline & Tamazula & 1580 & 996 & 0.06 & 0.11 & 0.05 & -1.58 & 0.65 & 2.02 \\
\hline \multirow{2}{*}{ Chihuahua } & El Tarahumar & 2435 & 916 & 0.11 & 0.31 & 0.31 & 0.60 & -0.08 & 0.7 \\
\hline & Guerachic & 780 & 627 & 2.33 & -1.24 & -1.56 & 2.46 & 2.35 & -1.11 \\
\hline Sonora & Don Huatabampo & 50 & 356 & -1.94 & -2.36 & -1.3 & -2.07 & 0.11 & 2.47 \\
\hline
\end{tabular}

E - elevation, $\bar{P}_{a}$ - average cumulative annual precipitation, $\bar{T}_{\max }-$ maximum temperature, $\bar{T}_{a v g}$ - average temperature, $\bar{T}_{\text {min }}-$ minimum temperature, $\bar{P}$ - cumulative annual precipitation, $\overline{P E T}$ - potential evapotranspiration, $\overline{A I}$ - aridity index Bold - significant trend indicators 
To identify the existence of ST, the Mann-Kendall test [19, $20]$ was performed. If the result of the standardized value of $Z\left(Z_{s t d}\right)$ is $>/ 1.96 /$, there is $95 \%$ confidence of an $S T$ in the time series; that is, the null hypothesis is rejected at significance level $\alpha=0.05$. Thus a positive value of $Z_{\text {std }}$ indicates a $P T$, and a negative value indicates an $N T$ in the data series [21]. $Z_{\text {std }}$ was calculated using the MOCLIC 1.0 program developed at the University of Mexico (UNAM). The inputs were monthly average temperature and rainfall data $\left(\bar{T}_{\max }\right.$, $\bar{T}_{a v g}, \bar{T}_{m i n}$, and $\bar{P}$ ) from the period 1970-2011. The goal of the study was to determine whether there were significant trends in any of these indicators. The magnitude of each trend was estimated using the method of Sen's slopes [3], in which the median is used as the estimated value of the trend after the data (all possible slopes that can be calculated for the series) have been ranked in ascending order [18, 22]. The Hargreaves ratio was used to calculate $\overline{P E T}$, which depends on $\bar{T}_{\max }, \bar{T}_{a v g}, \bar{T}_{\min }$; and $A I$ was calculated by the method proposed by [8] - which published the World Atlas of Desertification - to quantify the relationship between $\bar{P}_{a}$ and $\overline{P E T}$. To classify $A I$, the UNEP criteria were used: $>0.65$ humid, 0.65 to 0.5 dry sub-humid, 0.5 to 0.2 semiarid, 0.2 to 0.05 arid, and $<0.05$ hyper-arid. The inverse distance weighting $(I D W)$ method, calculated using the Surfer 10.0 program, was used to interpolate average annual trends. This deterministic interpolation method is one of the most commonly used methods to construct spatial data maps [9]. However, $I D W$ has the disadvantage that it tends to generate closed surfaces around the data when the power coefficient $(p)$ is small. Therefore we took into account the criteria of [3] using a greater power coefficient $(p)$ to produce smoother, more continuous surfaces. Thus, for the equipotential surfaces of the trend maps in this study, a power coefficient $p=2$ was used. The results of the $I D W$ interpolation were layered on urban outlines drawn using Corel Draw X6.

\section{Validation Maps}

To evaluate the variance between the observed and calculated results of the model, the variability of the parameters from each map $\left(T_{\max }, T_{\text {avg }}, T_{\min }\right.$ and $P$ ) was used. To validate the model, conventional statistical algorithms such as root mean squared error (RMSE), bias, and the Pearson correlation coefficients ( $\mathrm{r}$ ) and coefficient of determination $\left(\mathrm{R}^{2}\right)$ were used. The results were validated by comparing them with data from a government agency [23]. Validation of the model by comparing observed mean values (control) and calculated values did not result in large differences except in the case of rainfall precipitation at some weather stations, which was attributed to local climate change [24].

\section{Results and Discussion}

The $S T$ of each parameter varied geographically and are shown in Table 1 for the Mann-Kendall statistic (confidence level $=95 \%$ ). An $S T$ was identified in $\bar{T}_{\max }$ at 20 weather stations (17 PT and $3 T N$ ). The stations with the highest magnitude of $P T$ were Puerto San Carlos in BCS $\left(0.160^{\circ} \mathrm{C} \cdot \mathrm{yr}^{-1}\right)$, El Tarahumar in CHI $\left(0.113^{\circ} \mathrm{C} \cdot \mathrm{yr}^{-1}\right)$, and San Javier in $\mathrm{BCS}\left(0.104^{\circ} \mathrm{C} \cdot \mathrm{yr}^{-1}\right)$. The stations with the highest magnitude of $N T$ were Ligui in $\mathrm{BCS}\left(-0.113^{\circ} \mathrm{C} \cdot \mathrm{yr}^{-1}\right)$, Don Huatabampo in $\mathrm{SON}\left(-0.106^{\circ} \mathrm{C} \cdot \mathrm{yr}^{-1}\right)$, and Palmar de los Sepulveda in $\operatorname{SIN}\left(-0.102^{\circ} \mathrm{C} \cdot \mathrm{yr}^{-1}\right)$. The average of the $N T$ are similar to those calculated by [23] for the Palmar de los Sepulveda and Ligui stations. Average $P T$ showed a change of $0.030^{\circ} \mathrm{C} \cdot \mathrm{yr}^{-1}\left(0.30^{\circ} \mathrm{C} \cdot\right.$ decade $\left.^{-1}\right)$, which is similar to the values obtained by [23] for the increase in maximum average annual air temperature $\left(\bar{T}_{\max }\right)$ for the period 1979-2008 (Table 2) (Fig. 1; Map A). This overall increase in air temperature, as shown by the PT of $\bar{T}_{\max }$, could cause future negative impacts on climate, with repercussions in turn on agricultural and environmental systems in the region. Some examples of these effects are increased consumption of water by plants and animals, and altered biological cycles of some living organisms. Map A in Fig. 1 shows where weather stations with $P T$ and NT are clustered, and shows that some zones display abrupt changes within short distances, such as in the western part of BCS (Ligui and San Javier stations), which are attributed to homogeneous climate changes and trends with high variability. The analysis of $\bar{T}_{\text {avg }}$ showed ST at 24 stations (7PT and $17 N T$ ). The station with the highest magnitude of $P T$ was Guasave in SIN $\left(0.013^{\circ} \mathrm{C} \cdot \mathrm{yr}^{-1}\right)$. The stations with the greatest magnitude of $N T$ were Puerto San Carlos in SON $\left(-0.130^{\circ} \mathrm{C} \cdot \mathrm{yr}^{-1}\right)$ and Constitucion in $\operatorname{BCS}\left(-0.094^{\circ} \mathrm{C} \cdot \mathrm{yr}^{-1}\right)$. The average for stations with $N T$ was $-0.060^{\circ} \mathrm{C} \cdot \mathrm{yr}^{-1}$, and the average for stations with $P T$ was $0.072^{\circ} \mathrm{C} \cdot \mathrm{yr}^{-1}$ (Table 2 and Fig. 1, Map C). Without taking the $S T$ of the $P T$ into account, the average was $-0.002^{\circ} \mathrm{C} \cdot \mathrm{yr}^{-1}$, which differs from the result obtained by the [1] for the 100 year linear trend (1906-2005) of the $P T$ of average annual $\bar{T}_{\text {avg }}$, which was $0.74^{\circ} \mathrm{C}$ (between $0.56^{\circ} \mathrm{C}$ and $\left.0.92^{\circ} \mathrm{C}\right)$. The analysis of $\bar{T}_{\text {min }}$ showed trends at 21 stations (10 PT and $11 N T)$. The station with $P T$ and the highest values was Guasave in $\operatorname{SIN}\left(0.098^{\circ} \mathrm{C} \cdot \mathrm{yr}^{-1}\right)$ and the stations with the highest values of NT were Las Cruces in BCS $\left(-0.113^{\circ} \mathrm{C} \cdot \mathrm{yr}^{-1}\right)$ and El Refugio in $\operatorname{BCS}\left(-0.103^{\circ} \mathrm{C} \cdot \mathrm{yr}^{-1}\right)$. The cumulative average $T_{\min }\left(\bar{T}_{\min }\right)$ was $-0.004^{\circ} \mathrm{C} \cdot \mathrm{yr}^{-1}$ (Fig. 1).

The stations with $N T$ in $\bar{T}_{\text {min }}$ are associated with increases in the frequency and intensity of freezes, affecting the yield and profitability of crops and livestock, and causing considerable losses to crops of vegetables, fruits, flowers, potatoes, corn, fodder, and other produce [4] that support the local economy. The spatial variation of $\bar{T}_{\min }$ is shown in Fig. 1, Map B, with the highest values in the western and central part of the study area. In the same figure, the similarity between $\bar{T}_{\text {min }}$ and $\bar{T}_{\text {max }}$ can be seen. Of the 21 stations with $S T$ in $\bar{T}_{\text {min }}$, 13 showed changes in $\bar{T}_{\max }$ (Tables 1 and 2), supporting the hypothesis that climate changes are more prominent in some areas than in others where the trends have not been significant.

On a Worldwide scale, the nighttime increase in temperature has been almost twice the daytime increase, a pattern which has not been identified until now [1]. This behavior is an indicator that there has been a reduction in 
Table 2. Magnitude of trends of indicators estimated by Sen's slope method.

\begin{tabular}{|c|c|c|c|c|c|c|c|}
\hline \multicolumn{2}{|r|}{ Location } & \multicolumn{6}{|c|}{ Magnitude of change trend indicator } \\
\hline State & Weather station & $\bar{T}_{\max }\left({ }^{\circ} \mathrm{C} \cdot \mathrm{yr}^{-1}\right)$ & $\bar{T}_{\text {avg }}\left({ }^{\circ} \mathrm{C} \cdot \mathrm{yr}^{-1}\right)$ & $\bar{T}_{\min }\left({ }^{\mathrm{o}} \mathrm{C} \cdot \mathrm{yr}^{-1}\right)$ & $\bar{P}\left(\mathrm{~mm} \cdot \mathrm{yr}^{-1}\right)$ & $\overline{P E T}\left(\mathrm{~mm} \cdot \mathrm{yr}^{-1}\right)$ & $\overline{A I}$ (Dimensionless) \\
\hline \multirow{13}{*}{ Sinaloa } & Acatitan & 0.021 & -0.054 & -0.023 & 9 & -58 & -1.125 \\
\hline & Culiacan & 0.060 & -0.083 & -0.048 & -28 & 62 & 1.010 \\
\hline & El Playon & 0.053 & 0.032 & -0.070 & -9 & 53 & 0.692 \\
\hline & Guasave & 0.110 & 0.130 & 0.098 & 18 & 56 & -0.660 \\
\hline & Guatenipa & 0.073 & -0.067 & -0.018 & -15 & -56 & 1.477 \\
\hline & Jaina & -0.046 & -0.077 & 0.060 & -15 & -56 & 1.264 \\
\hline & Palmar de Los S. & -0.102 & -0.094 & 0.065 & -20 & -57 & 0.886 \\
\hline & Pericos & -0.035 & -0.088 & 0.067 & 8 & -57 & -0.965 \\
\hline & Ruiz Cortinez & 0.040 & 0.077 & 0.029 & 10 & -55 & -0.567 \\
\hline & Santa Cruz & -0.050 & -0.040 & -0.031 & 13 & -55 & 1.123 \\
\hline & Siqueros & 0.059 & -0.043 & -0.045 & -11 & -57 & 1.021 \\
\hline & Surutato & 0.060 & 0.060 & 0.030 & 25 & 56 & -1.510 \\
\hline & Topolobampo & 0.083 & 0.117 & 0.086 & 18 & -49 & 0.492 \\
\hline \multirow{16}{*}{$\begin{array}{c}\text { Baja } \\
\text { California } \\
\text { Sur }\end{array}$} & Caduaco & -0.031 & -0.053 & 0.053 & 11 & -64 & -0.550 \\
\hline & Constitución & 0.034 & -0.094 & -0.041 & -8 & 55 & 0.199 \\
\hline & El Paso de Iritu & 0.031 & -0.045 & -0.058 & 10 & 56 & -0.243 \\
\hline & El Refugio & -0.029 & -0.076 & -0.103 & 4 & 54 & -0.114 \\
\hline & El Rosario & 0.077 & -0.049 & -0.063 & -12 & 58 & 0.147 \\
\hline & La Paz & 0.044 & -0.019 & -0.066 & -5 & 54 & 0.253 \\
\hline & La Poza Grande & 0.063 & 0.069 & -0.046 & 3 & 50 & 0.086 \\
\hline & La Purísima & 0.051 & -0.077 & -0.061 & 3 & 56 & 0.142 \\
\hline & La Soledad & 0.059 & 0.077 & 0.064 & 15 & -58 & -0.316 \\
\hline & Las Cruces & 0.071 & 0.100 & -0.113 & 6 & 54 & 0.158 \\
\hline & Ligui & -0.113 & -0.053 & 0.040 & 17 & -54 & 0.253 \\
\hline & Los Divisaderos & 0.093 & 0.047 & 0.033 & 7 & -51 & 0.688 \\
\hline & Penjamo & -0.070 & 0.120 & 0.063 & -5 & -58 & 0.173 \\
\hline & Puerto San Carlos & 0.160 & -0.130 & -0.080 & 5 & -42 & 0.140 \\
\hline & San Javier & 0.104 & 0.045 & 0.075 & 10 & 53 & 0.414 \\
\hline & Todos Santos & -0.025 & -0.059 & -0.049 & 5 & -48 & 0.267 \\
\hline \multirow{6}{*}{ Durango } & Huahuapan & -0.034 & 0.021 & 0.037 & 9 & 49 & -1.408 \\
\hline & Ojito de Camellones & 0.030 & -0.068 & -0.058 & 29 & -36 & -3.563 \\
\hline & Pena de Águila & 0.049 & -0.021 & -0.020 & 6 & -44 & 1.033 \\
\hline & San Miguel de Lobos & 0.044 & 0.087 & 0.050 & -11 & 35 & -2.020 \\
\hline & Santiago Papasquiaro & 0.059 & 0.031 & 0.039 & 7 & 47 & -0.910 \\
\hline & Tamazula & 0.061 & 0.114 & 0.053 & 21 & 53 & 1.592 \\
\hline \multirow{2}{*}{ Chihuahua } & El Tarahumar & 0.113 & 0.125 & 0.030 & 14 & -34 & 2.231 \\
\hline & Guerachic & 0.089 & 0.039 & -0.043 & 15 & 53 & -1.081 \\
\hline Sonora & Don Huatabampo & -0.106 & -0.080 & -0.068 & -8 & 59 & 0.594 \\
\hline
\end{tabular}

$\bar{P}_{a}$ - average cumulative annual precipitation, $\bar{T}_{\max }$ - maximum temperature, $\bar{T}_{a v g}$-average temperature, $\bar{T}_{\min }-$ minimum temperature, $\bar{P}$ - cumulative annual precipitation, $\overline{P E T}$ - potential evapotranspiration, $\overline{A I}$ - aridity index

Bold - significant trend indicators 
Table 3. Trend observed and calculated of the temperature $\left({ }^{\circ} \mathrm{C} \cdot \mathrm{yr}^{-1}\right)$ and precipitation $\left(\mathrm{mm} \cdot \mathrm{yr}^{-1}\right)$ in northern Mexico.

\begin{tabular}{|c|c|c|c|c|c|c|c|c|}
\hline \multirow[b]{3}{*}{ Weather station } & \multicolumn{8}{|c|}{ Trends } \\
\hline & \multicolumn{2}{|c|}{$\bar{T}_{\max }$} & \multicolumn{2}{|c|}{$\bar{T}_{a v g}$} & \multicolumn{2}{|c|}{$\bar{T}_{\min }$} & \multicolumn{2}{|c|}{$\bar{P}$} \\
\hline & Obs & Calc & Obs & Calc & Obs & Calc & Obs & Calc \\
\hline Acatitan & 0.024 & 0.021 & -0.041 & -0.054 & -0.020 & -0.023 & 6 & 9 \\
\hline Culiacan & 0.022 & 0.060 & -0.072 & -0.083 & -0.014 & -0.048 & -10 & -28 \\
\hline El Playon & 0.099 & 0.053 & 0.026 & 0.032 & -0.062 & -0.070 & -7 & -9 \\
\hline Guasave & 0.110 & 0.110 & 0.098 & 0.130 & 0.093 & 0.098 & 10 & 18 \\
\hline Guatenipa & 0.099 & 0.073 & -0.048 & -0.067 & -0.015 & -0.018 & -5 & -15 \\
\hline Jaina & -0.036 & -0.046 & -0.066 & -0.077 & 0.099 & 0.060 & -8 & -15 \\
\hline Palmar de Los S. & -0.044 & -0.102 & -0.085 & -0.094 & 0.038 & 0.065 & -13 & -20 \\
\hline Pericos & -0.042 & -0.035 & -0.074 & -0.088 & 0.040 & 0.067 & 7 & 8 \\
\hline Ruiz Cortinez & 0.048 & 0.040 & 0.040 & 0.077 & 0.061 & 0.029 & 5 & 10 \\
\hline Santa Cruz & -0.043 & -0.050 & -0.035 & -0.040 & -0.015 & -0.031 & 10 & 13 \\
\hline Siqueros & 0.066 & 0.059 & -0.037 & -0.043 & -0.030 & -0.045 & -8 & -11 \\
\hline Surutato & 0.050 & 0.060 & 0.035 & 0.060 & 0.006 & 0.030 & 8 & 25 \\
\hline Topolobampo & 0.080 & 0.083 & 0.098 & 0.117 & 0.030 & 0.086 & 10 & 18 \\
\hline Caduaco & -0.030 & -0.031 & -0.036 & -0.053 & 0.063 & 0.053 & 8 & 11 \\
\hline Constitución & 0.095 & 0.034 & -0.124 & -0.094 & -0.043 & -0.041 & -6 & -8 \\
\hline El Paso de Iritu & 0.028 & 0.031 & -0.025 & -0.045 & -0.051 & -0.058 & 4 & 10 \\
\hline El Refugio & -0.027 & -0.029 & -0.038 & -0.077 & -0.101 & -0.103 & 2 & 4 \\
\hline El Rosario & 0.096 & 0.077 & -0.042 & -0.049 & -0.043 & -0.063 & -8 & -12 \\
\hline $\mathrm{La} \mathrm{Paz}$ & 0.044 & 0.044 & -0.022 & -0.019 & -0.034 & -0.066 & -4 & -5 \\
\hline La Poza Grande & 0.060 & 0.063 & 0.042 & 0.069 & -0.022 & -0.046 & 2 & 3 \\
\hline La Purísima & 0.023 & 0.051 & -0.067 & -0.077 & -0.070 & -0.061 & 3 & 3 \\
\hline La Soledad & 0.032 & 0.059 & 0.058 & 0.077 & 0.081 & 0.064 & 8 & 15 \\
\hline Las Cruces & 0.056 & 0.071 & 0.085 & 0.100 & -0.105 & -0.113 & 6 & 6 \\
\hline Ligui & -0.105 & -0.113 & -0.035 & -0.053 & 0.035 & 0.040 & 12 & 17 \\
\hline Los Divisaderos & 0.101 & 0.093 & 0.028 & 0.047 & 0.038 & 0.033 & 5 & 7 \\
\hline Penjamo & -0.065 & -0.070 & 0.010 & 0.120 & 0.055 & 0.063 & -4 & -5 \\
\hline Puerto San Carlos & 0.096 & 0.160 & -0.025 & $-\mathbf{0 . 1 3 0}$ & -0.043 & -0.080 & 3 & 5 \\
\hline San Javier & 0.071 & 0.104 & 0.026 & 0.045 & 0.041 & 0.075 & 8 & 10 \\
\hline Todos Santos & -0.030 & -0.025 & -0.050 & -0.059 & -0.041 & -0.049 & 2 & 5 \\
\hline Huahuapan & -0.035 & -0.034 & 0.023 & 0.021 & 0.035 & 0.037 & 7 & 9 \\
\hline Ojito de Camellones & 0.034 & 0.030 & -0.057 & -0.068 & -0.042 & -0.058 & 12 & 29 \\
\hline Peña de Águila & 0.040 & 0.049 & -0.020 & -0.021 & -0.025 & -0.020 & 5 & 6 \\
\hline San Miguel de Lobos & 0.037 & 0.044 & 0.074 & 0.087 & 0.045 & 0.050 & -9 & -11 \\
\hline Santiago Papasquiaro & 0.040 & 0.059 & 0.027 & 0.031 & 0.035 & 0.039 & 5 & 7 \\
\hline Tamazula & 0.049 & 0.061 & 0.093 & 0.114 & 0.042 & 0.053 & 15 & 21 \\
\hline El Tarahumar & 0.095 & 0.113 & 0.034 & 0.125 & 0.026 & 0.030 & 10 & 14 \\
\hline Guerachic & 0.071 & 0.089 & 0.041 & 0.039 & -0.040 & -0.043 & 10 & 15 \\
\hline Don Huatabampo & -0.102 & -0.106 & -0.070 & -0.080 & -0.061 & -0.068 & -6 & -8 \\
\hline
\end{tabular}

$\bar{T}_{\text {max }}$ - maximum temperature, $\bar{T}_{\text {avg }}$ - average temperature, $\bar{T}_{\text {min }}-$ minimum temperature, $\bar{P}$ - cumulative annual precipitation, Obs observed trend, Calc - calculed trend, Bold - significant trend indicators 
freezes and colder-than-normal days, and an increase in hot days over the previous century [1]. This behavior is partly valid; although there is an increase in daytime temperature overall, the $N T$ of $\bar{T}_{\text {min }}$ show high $S T$, which implies cold nights and an increase in the probability of freeze events.

ST results for $\bar{P}_{a}$ were found at only 6 stations ( $4 P T$ and $2 \mathrm{NT}$ ), with an average of $4 \mathrm{~mm} \cdot \mathrm{yr}^{-1}$ (Table 2 and Fig. 2, Map A). For this reason, the results involving $S T$ of local climate change are less significant for $P$ than $T$ (Table 1 and Fig. 2, Map A). The stations with the greatest magnitudes and $P T$ were Guerachic in CHI $\left(15 \mathrm{~mm} \cdot \mathrm{yr}^{-1}\right)$ and Caduaco in BCS $\left(11 \mathrm{~mm} \cdot \mathrm{yr}^{-1}\right)$, and those with high values and $N T$ were El Playón in SIN (-9 mm·yr $\left.{ }^{-1}\right)$. The $S T$ for $\bar{P}$ are similar to the [1] results, and do not indicate any evident trends in $\bar{P}_{a}$. PET showed $S T$ at 20 stations (9NT and $11 P T$ ), and an overall average of $1 \mathrm{~mm} \cdot \mathrm{yr}^{-1}$. The total at stations with NT was $-53 \mathrm{~mm} \cdot \mathrm{yr}^{-1}$ and of stations with $P T$ it was 52 $\mathrm{mm} \cdot \mathrm{yr}^{-1}$. The stations with the greatest variation in $P T$ were

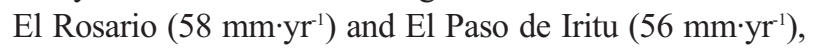
both in BCS. The stations with the greatest magnitude of NT were Caduaco in BCS (-64 mm· $\left.\mathrm{yr}^{-1}\right)$ and Acatitan in $\operatorname{SIN~}\left(-58 \mathrm{~mm} \cdot \mathrm{yr}^{-1}\right)$.

For the analysis of $A I$, there were ST at 7 stations (2 NT and $5 P T$ ), the greatest magnitudes being $P T$ at Tamazula in DGO (1.592) and Palmar de Los Sepúlveda in SIN (0.886), and NT at Huahuapan in DGO (-1.408). When statistical significance was taken into account, the average $N T$ of $A I(A \bar{I})$ was -0.761 and of $P T$ the $A I$ was 0.836 . When the level of statistical significance was not taken into account, $A I$ was 0.034 (Tables 1 and 2 and Fig. 3). It is vitally important to know where $A I$ shows $S T$, because adaptation and mitigation measures can be taken; such as designing construction for extreme temperatures, designing and constructing coastal infrastructure to reduce the impact of storms, identifying highly vulnerable areas, and designing plans to reduce risk, and decreasing greenhouse gas emissions [23]. The $\bar{T}_{\max }, \bar{T}_{a v g}$, and $\bar{T}_{\min }$ results specifically in the zone of Guasave in SIN suggest that these adaptation and mitigation measures should be intensified, since the natural variability, given the $S T$ shown by $P$ and $T$ could be the main factor explaining hysteresis in the variability of agricultural production, which has suffered repeated freezes in recent years, with repercussions on food security [25].

Another important zone in SIN is the region near the El Playón station, since it showed $S T$ in $\bar{T}_{\max }, \bar{T}_{\min }, \bar{P}, \overline{P E T}$, and $\overline{A I}$ and it is close to the Ensenada de Pabellones wetlands, Ramsar 13 and 14 of the San Ignacio Navachiste-Macapule lagoon complex. Similar actions to minimize climate change should be undertaken to decrease climate effects in the area of the San Javier and La Purisima stations in BCS, as they showed $S T$ in $\bar{T}_{\max }, \bar{T}_{a v g}, \bar{T}_{\min }, \bar{P}, \overline{P E T}$, and $\overline{A I}$, and are located close to Ramsar wetlands numbers 2, 3, 4, 5, and 6 (Laguna San Ignacio, Sierra de Guadalupe, Los Comondú, Oasis Sierra de La Giganta, and Bahía de Loreto National Park), which are among the ecosystems under threat at the World level (Fig. 3) [26]. In SIN, $\overline{A I}$ ranged from semiarid to humid with values of -1.510 (Surutato) to 1.477 (Guatenipa). The variation in BCS was arid to dry sub-humid with values from -0.550 (Caduaco) to 0.688 (Los Divisaderos).

In DGO all stations were humid, ranging from -3.563 (Ojito of Camellones) to 1.592 (Tamazula). The same pattern was seen in Chihuahua as in DGO, with extreme values of -1.081 (Guerachic) and 2.231 (El Tarahumar). With a value of 0.594 , the one station located in SON was classified as dry sub-humid (Don Huatabampo) (Fig. 3). Although some stations showed NT, the overall trend in this variable from 1970 to 2011 has been increasing, with significant increases at the Puerto San Carlos station in the western part of BCS, where the increase was $1.6^{\circ} \mathrm{C} \cdot$ decade $^{-1}$.

One of the notable results was the NT in $\bar{T}_{\text {min }}$ in SIN, which reflected climate changes in the Guasave station zone. The cooling that has taken place in the local area around this agricultural region should be the subject of further detailed study. This is because agriculture plays a key role in local and national economic development; climate change requires modern society to work together to adapt food systems to achieve food security, alleviation of poverty, sustainable management, and conservation of natural resources. Some climate change adaptation measures that could be integrated into the economy of the region would be development of seed varieties resistant to climate change, emerging plans to deal with water scarcity and droughts, training human resources about climate change, and research tools that reinforce the adoption of practices that reduce disasters and the risk of food insecurity. Another event of interest is the behavior of $\bar{T}_{a v g}$, where there is a $N T$ at the tourist port of San Carlos. This is a result which should also be taken into account to promote adaptation in tourism and the local population, because of the effects of cold air on human health. It is important to give tourists and local residents information about these climate trends to avoid potential respiratory illness.

Overall, $\mathrm{P}$ did not show an $S T$ at a large number of stations, but the $S T$ s that were found indicate annual increases in rainwater volumes. Excess rainfall affects soil and crops and promotes natural enemies such as pests and diseases to balance the environmental system [26]. Given the important role of wetlands in the capture and storage of atmospheric carbon, it is recommended to replant and care for wetlands [1] to mitigate effects of $A I$.

Some actions that can be taken, among others, are to develop plans and programs for the management of each wetland according to its needs and/or characteristics, and to identify its areas of influence and its flora and fauna. Meeting the stated objectives would help to avoid effects such as increased water consumption by plants and animals, altered hydrologic and biological cycles in living organisms, and damage to agriculture, tourism, and industry, among others. These are consequences that could be prevented with a better understanding and knowledge of climate change. In contrast to atmospheric circulation models that have low spatial resolution and are not able to distinguish local features of systems [26], this methodology 


\section{Map A}
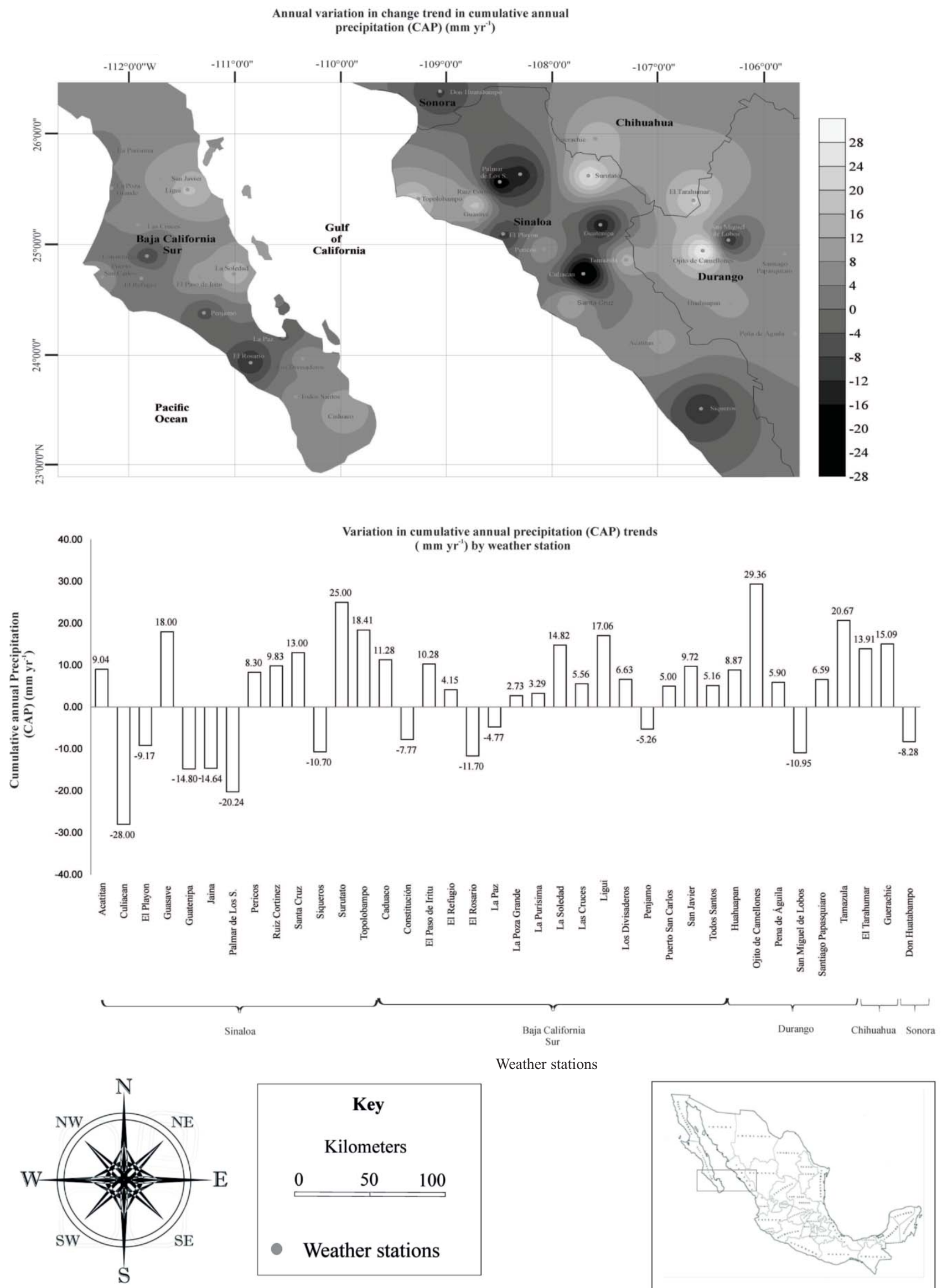

Fig. 2. Magnitude of change trends in P (Map A) and PET (Map B) in states in northern Mexico with high agricultural productivity. 


\section{Map B}

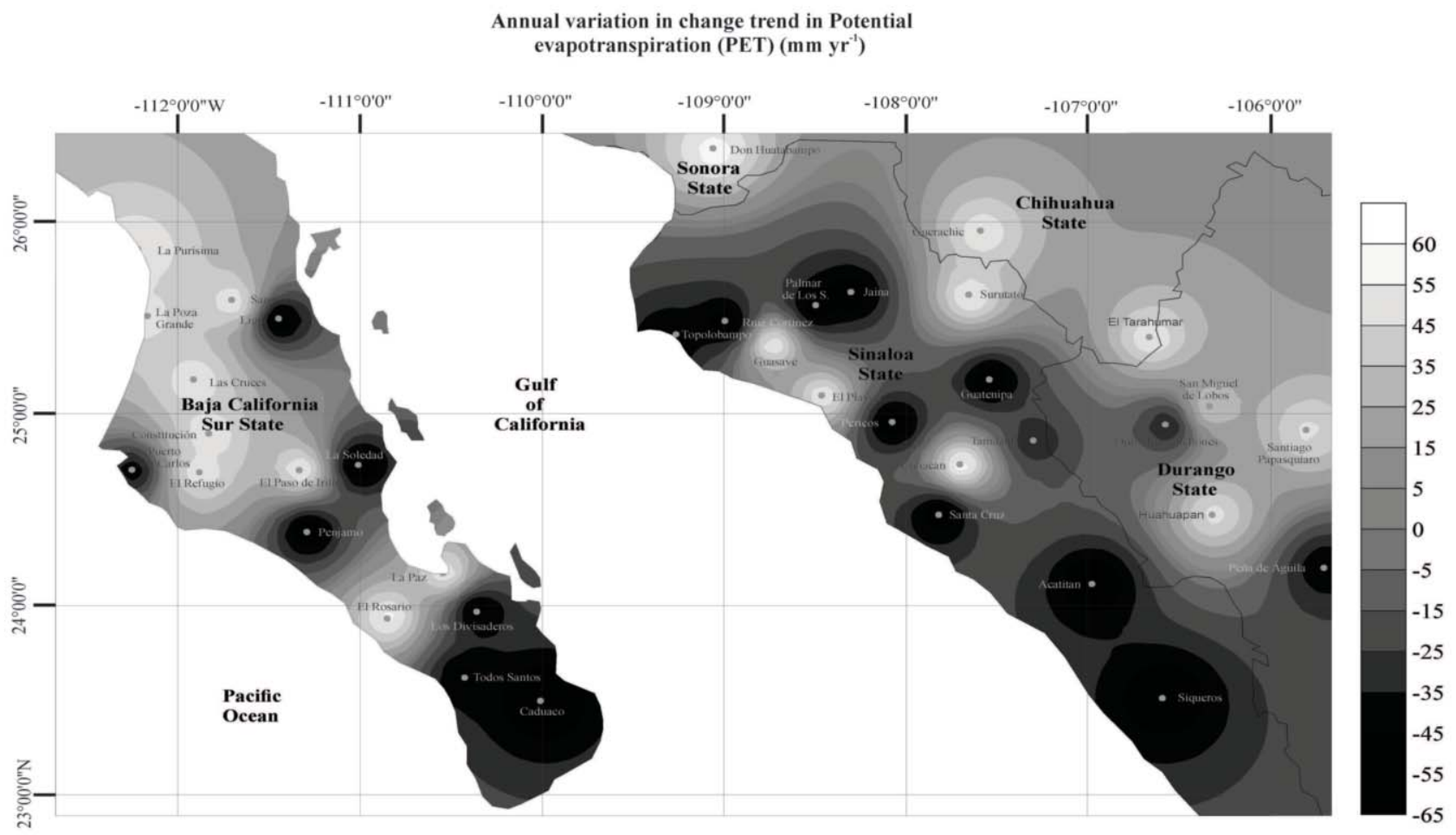

Variation in Potential evapotranspiration (PET) $\left(\mathrm{mm} \mathrm{yr}^{-1}\right)$ trend

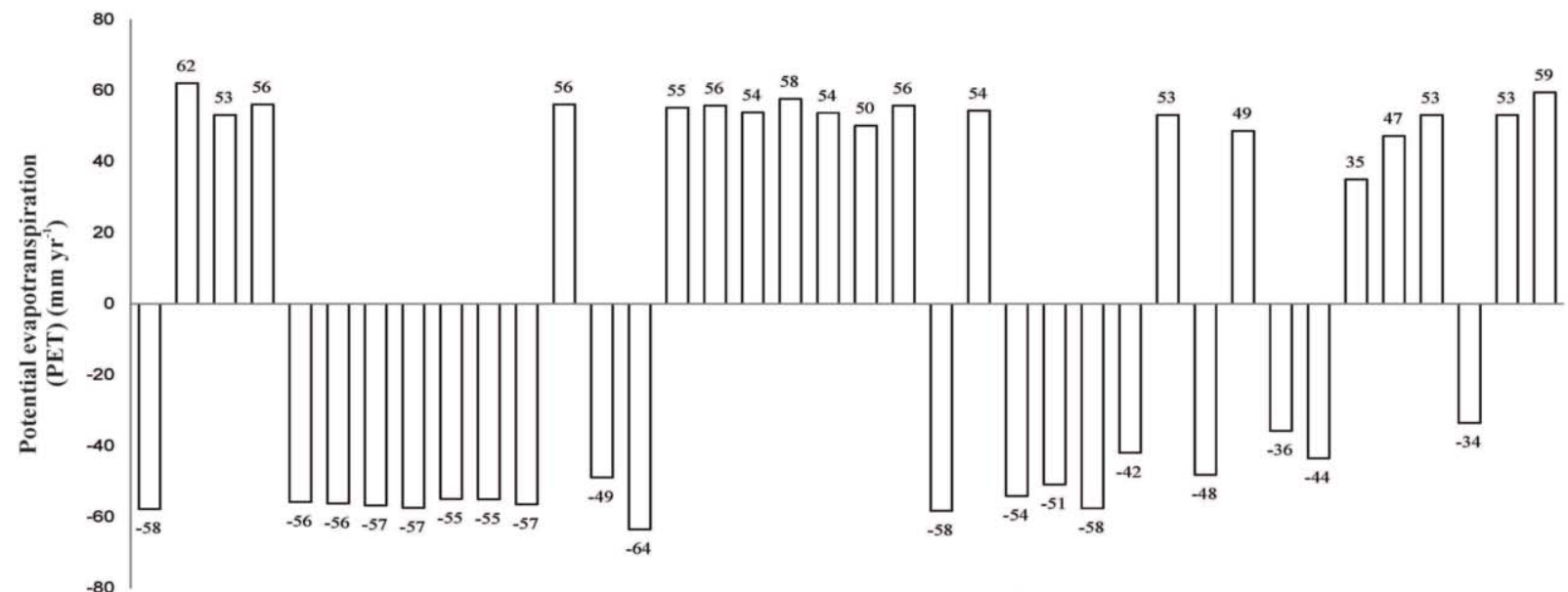

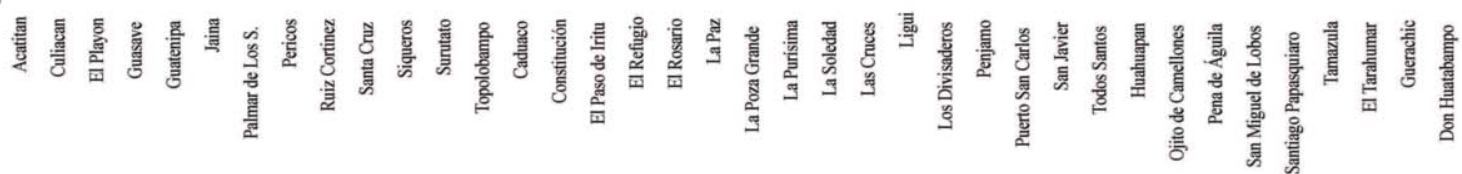

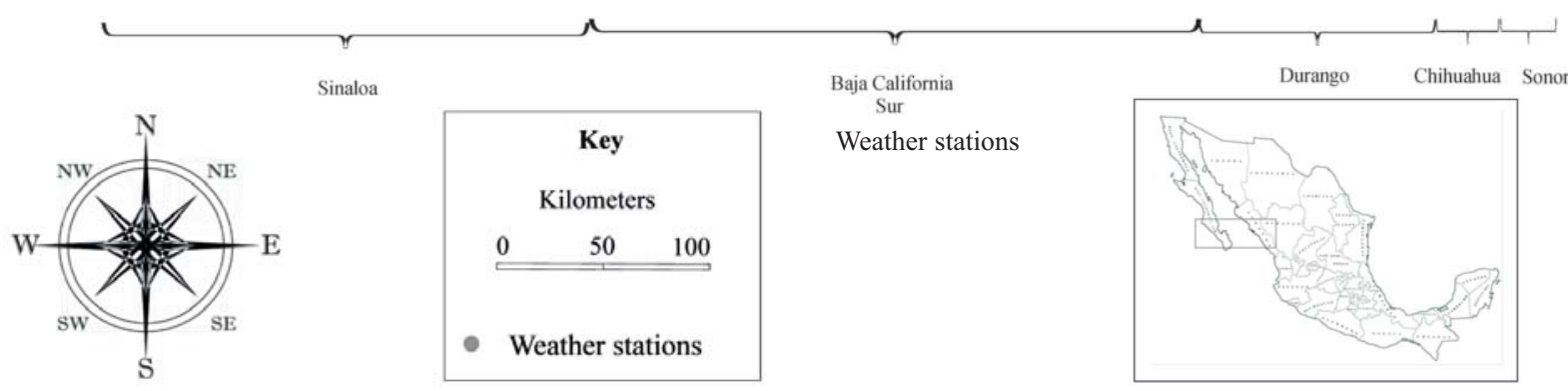

Fig. 2. Continued 
provides information about climate change and the impact on PET and $A I$ at the local scale, which is invaluable for guiding future research. Local results have shown that research on atmosphere flows cannot be framed only in terms of general circulation models [1]. Table 3 shows the observed and calculated trend of $\bar{T}_{\max }, \bar{T}_{a v g}$, and $\bar{T}_{\min }$, and $\bar{P}$. The average RMSE of $T_{\max }=0.02$, of $T_{\text {avg }}=0.03$, of $T_{\min }=$
0.02 , and of $P=6.39$. The $N M A E$ for these variables was, respectively, $0.18,0.25,0.03$, and 0.24 , and the bias was $0.0004,0.0006,0.0004$, and 0.1203 . Note that the comparison between trends in $T$ did not show significant changes, but $P$ showed the greatest variability among the precisions of the differences measured in the trends between in the values obtained in this study and the reference values.

Annual change in the aridity index (AI) trend (dimensionless)

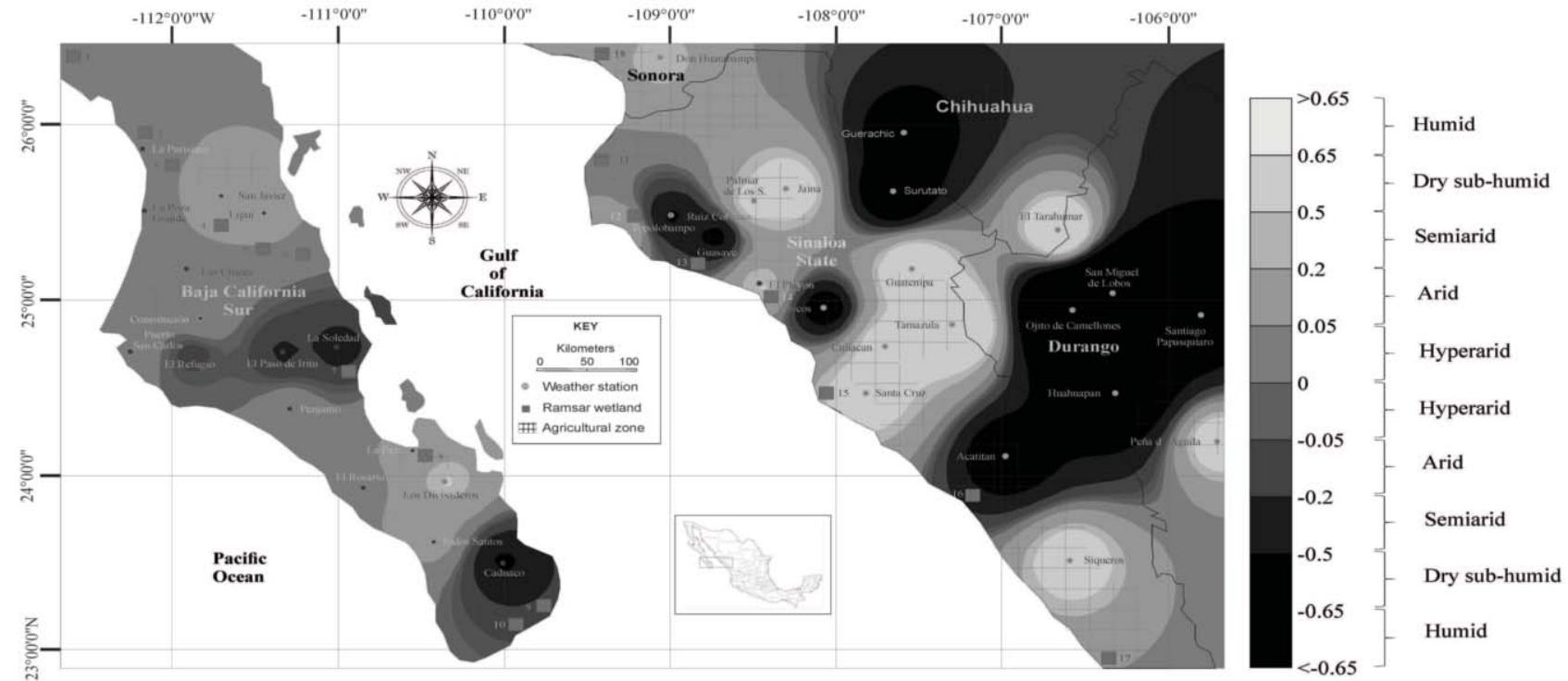

Annual change trend in aridity index (AI) (dimensionless)

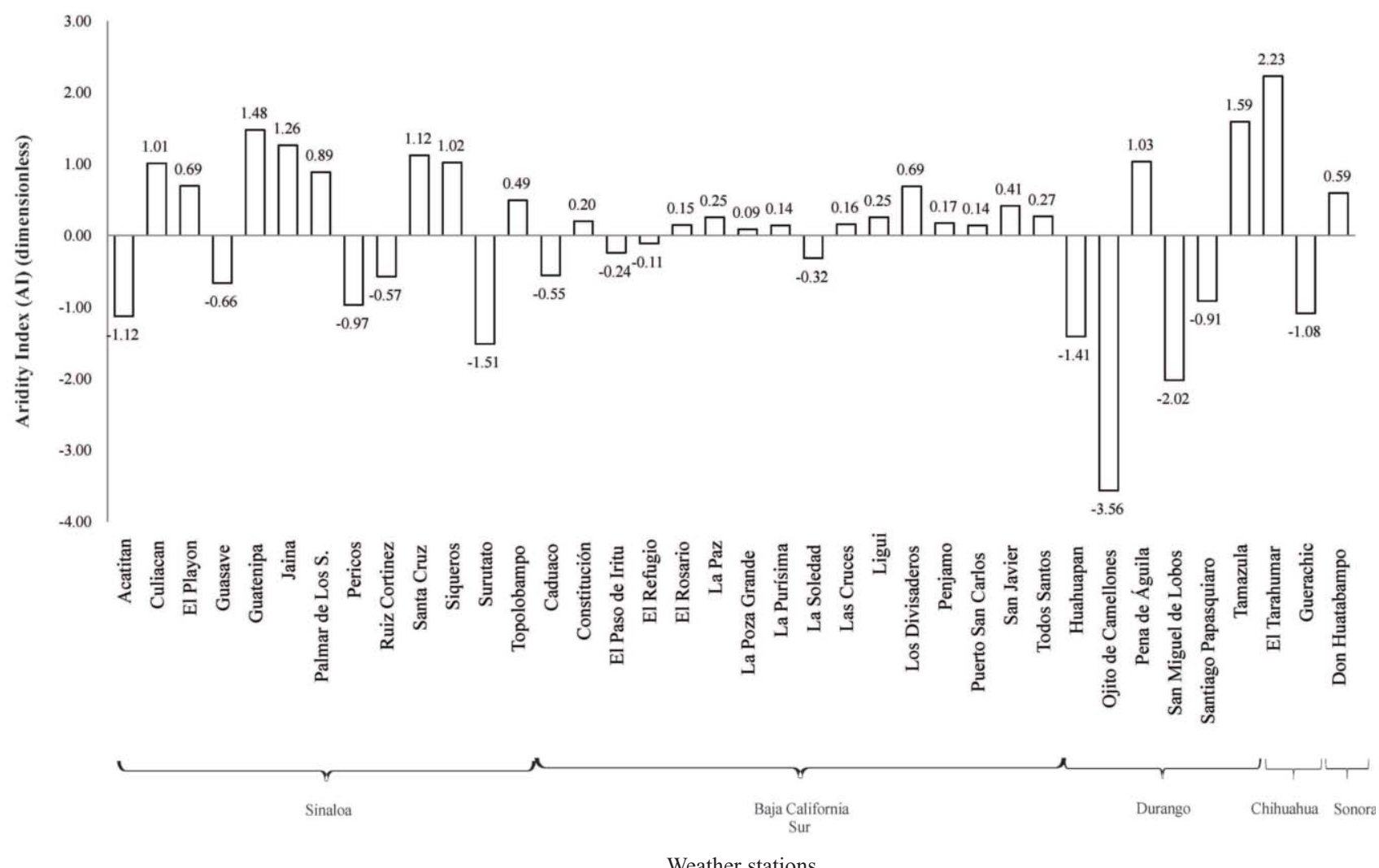

Fig. 3. Magnitude of change trends in $A I$ in states in northern Mexico with high agricultural productivity. 


\section{Ramsar wetlands}

\begin{tabular}{|c|c|c|c|}
\hline State & Name & Number on map & $\begin{array}{l}\text { Ramsar } \\
\text { number }\end{array}$ \\
\hline \multirow{10}{*}{$\begin{array}{l}\text { Baja California } \\
\text { Sur }\end{array}$} & Laguna Ojo de Liebre & 1 & 1339 \\
\hline & Laguna of San Ignacio & 2 & 1341 \\
\hline & La sierra de Guadalupe & 3 & 1815 \\
\hline & Los Comondú & 4 & 1761 \\
\hline & Oasis Sierra de la Giganta & 5 & 1793 \\
\hline & Parque nacional bahía de Loreto & 6 & 1358 \\
\hline & Oasis de la sierra El Pilar & 7 & 1794 \\
\hline & Humedales El Mogote-Ensenada La Paz & 8 & 1816 \\
\hline & Parque nacional Cabo Pulmo & 9 & 1778 \\
\hline & $\begin{array}{c}\text { Sistema ripario de la cuenca y estuario } \\
\text { de San José del Cabo }\end{array}$ & 10 & 1827 \\
\hline \multirow{7}{*}{ Sinaloa } & $\begin{array}{l}\text { Sistema lagunar Agiabampo - } \\
\text { Bacorehuis - río Fuerte }\end{array}$ & 11 & 1797 \\
\hline & $\begin{array}{c}\text { Lagunas de Santa María Topolobampo- } \\
\text { Ohuira }\end{array}$ & 12 & 2025 \\
\hline & $\begin{array}{c}\text { Sistema Lagunar San Ignacio } \\
\text { Navachiste-Macapule }\end{array}$ & 13 & 1826 \\
\hline & Ensenada de Pabellones & 14 & 1760 \\
\hline & Laguna Huizache-Caimanero & 15 & 1689 \\
\hline & $\begin{array}{l}\text { Laguna Playa Colorada - Santa María } \\
\text { La Reforma }\end{array}$ & 16 & 1327 \\
\hline & Sistema lagunar Ceuta & 17 & 1824 \\
\hline Sonora & $\begin{array}{c}\text { Complejo lagunar bahía Guásimas - } \\
\text { Estuario Lobos }\end{array}$ & 18 & 1790 \\
\hline
\end{tabular}

Fig. 3. Continued.

This was attributed to the fact that 8 of the 38 stations analyzed for $P$ showed high values. These were the Culiacan, Guasave, Guatenipa, Surutato, El Paso de Iritu, La Soledad, and Ojito de Camellones stations, located in different states but in very similar environmental systems. The values of the Pearson correlation for the variables are $\bar{T}_{\max }=0.93$, $\bar{T}_{\text {avg }}=0.92, \bar{T}_{\text {min }}=0.94$, and $P=0.95$, and their respective coefficients of determination are $\bar{T}_{\max }=0.87, \bar{T}_{\text {avg }}=0.84$, $\bar{T}_{\min }=0.89$, and $P=0.90$.

These statistics (Fig. 4; Map A-D) show that there is little variation between the values obtained in the study and the reference values. Variation in the trends between the observed and calculated values of $P$ are also attributed to the fact that the controls were measured in 2000 and calculated in 2011; a considerable time span. The values obtained for RMSE, bias, the Pearson correlation coefficient (r) and the coefficient of determination $\left(\mathrm{R}^{2}\right)$ do not show significant differences between the control values and the calculated values.

\section{Conclusion}

The $S T$ for $T$ are more pronounced than those for $P$. This suggests future changes in optimal conditions of the Ramsar wetlands and agricultural regions in the states of northern Mexico. No significant correlations were found in
$T$ between daytime $S T$ and nighttime $S T$. The results of this study can be used for land management or to suggest changes in land use in agricultural systems. Studies of this nature should be prioritized to direct the course of future research in climate change and accurately understand its local impact. It is vital to characterize climate change in northern Mexico, since environmental conservation and adaptation of economic activities are necessary. Wetlands, tourist areas, agriculture, livestock, forestry, fisheries, and aquaculture are some of the many activities that support the regional economy.

The methodology presented here to draw continuous surfaces from point data (IDW method) can be extended and adapted to other parts of the country. In future studies, the limitations of the method for the spatial distribution of the variables should be taken into consideration, since it depends only on the distance between points. A suggestion for improving $S T$ maps, such as $\bar{P}_{a}$ and $\overline{P E T}$ maps, in future work is to try other methods for interpolation of climate trend variables. These methods should be validated on the basis of their usefulness in providing greater certainty to the spatial distribution maps, and also, if possible, to include other variables such as elevation and the slope of the terrain, ground cover, and geographical characteristics that influence the spatial distribution of climate variables and their change trends over time where weather stations are closer together. Thus, the methodology provides an effi- 
A

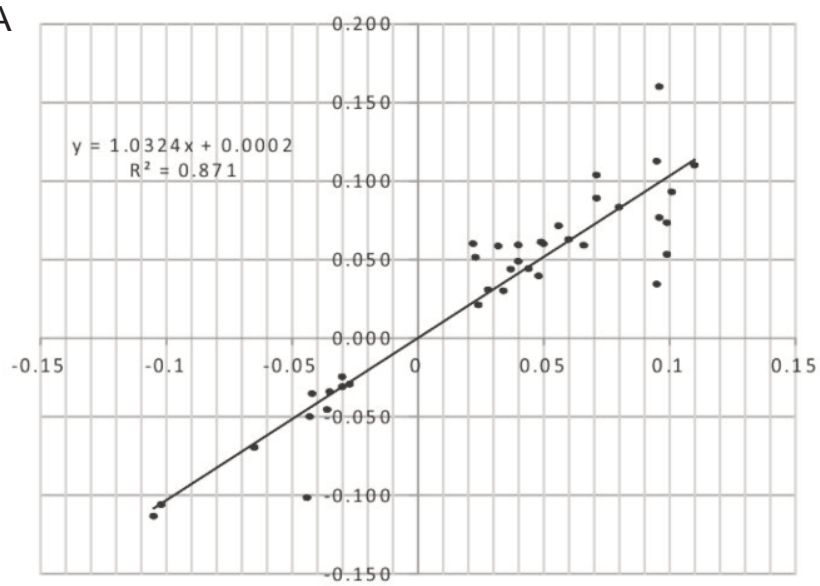

C

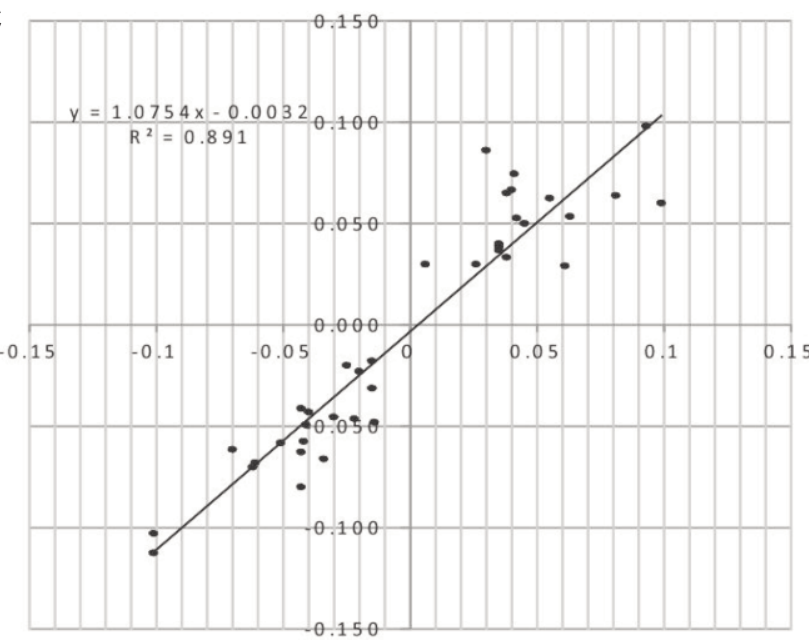

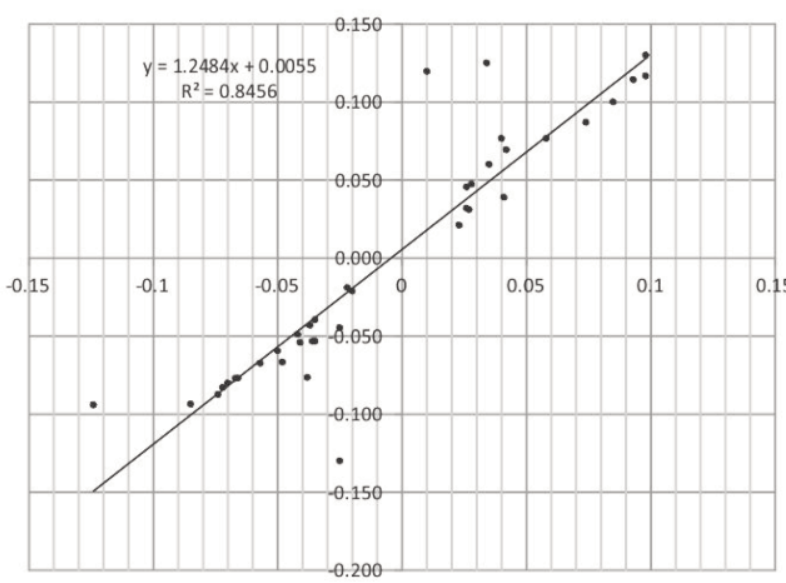

$\mathrm{D}$

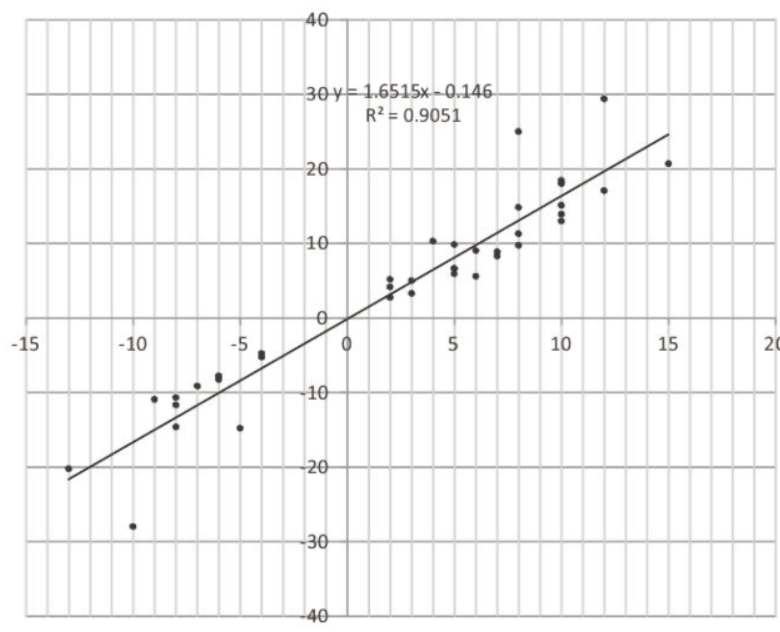

Fig. 4. Linear regressions between the observed and calculated values of temperature $\left({ }^{\circ} \mathrm{C} \cdot \mathrm{yr}^{-1}\right)$ and cumulative annual precipitation $\left(\mathrm{mm} \cdot \mathrm{yr}^{-1}\right)$.

cient way to detect and quantify the impacts of climate change at the local level, even when neither longterm climate time series ( $>50$ years) nor powerful computing resources are available.

No prior publications that give $S T$ for $A \bar{I}$ were found. Given the environmental damage caused by extreme values of this variable, it should be prioritized in subsequent research agendas. Until then, this methodology and the resulting maps show the areas at risk of potential impacts of $A \bar{I}$ due to past trends of $\bar{T}$ and $\bar{P}$. The trends calculated in this study were compared to results from [23]. Correlation coefficients of $0.93,0.92,0.94$, and 0.95 were obtained for $\bar{T}_{\text {max }}, \bar{T}_{a v g}$, and $\bar{T}_{\text {min }}$, and $\bar{P}$, respectively, supporting the validity of this study.

\section{Acknowledgements}

We thank to the assistants and staff of the Climate Lab of CIIDIR-IPN (Sinaloa) and CIBNOR SC (Baja California Sur). The SEP-CONACyT Sectorial Fund of Mexico, Project CB-2009-01-0134460, supported this study.

\section{References}

1. IPCC. The physical Science Basis. pp. 33, 2013.

2. LENDERINK G., MEIJGAARD V.E. Increase in hourly precipitation extremes beyond expectations from temperature changes. Nature Geoscience 1, 511, 2008. doi:10.1038/ngeo262

3. ROJAS E., ARCE B., PEÑA A., BOSHELL F., AYARZA M. Quantification and interpolation of local temperature and precipitation trends in high Andean zones of Cundinamarca and Boyacá (Colombia). Revista Corpoica - Ciencia y Tecnología Agropecuaria: 11, (2), 173, 2010.

4. STERN N. H., TREASURY, G. B. The Economics of Climate Change: The Stern Review, Cambridge University Press. 2007.

5. NICHOLLS, R.J., CAZENAVE A. Sea-level rise and its impact on coastal zones, Science (New York) 328(5985): pp. 1517-20, http://www.ncbi.nlm.nih.gov/pubmed/20558707. (Accessed: June 29, 2013). 2010.

6. CROMPTON R., McANENENEY J. The cost of natural disasters in Australia: The case for disaster risk reduction, The Australian Journal of Emergency Management, 23, (4), 43, 2008.

7. HARGREAVES G.H., SAMANI S.A. Reference crop evapotranspiration from temperature. Appl. Eng. Agric. ASAE, 1, (2), 96, 1985. 
8. ANÓNIMO. World Atlas of Desertification. UNEP. Edward Arnold, Sevenoaks, UK. 1992.

9. DÍAZ P., SÁNCHEZ I., QUIROZ R., GARATUZA P., WATTS T., CRUZ I. Spatial interpolation of rainfall precipitation in the windward and leeward zone of the Gulf of Mexico. Agricultura Técnica en México 34, (3), 279, 2008.

10. NORZAGARAY C. M., MUÑOZ S. P., SÁNCHEZ V. L., CAPURRO F. L. LLANES C. O. Aquaculture: Current status and research challenges in Mexico. Revista AquaTIC. 37, (1), 1, 2012.

11. LLANES C. O., NORZAGARAY C. M., MAYA D. Y., MUÑOZ S. P., BELTRÁN M. F. A., MURILLO A. B., TROYO D. E. Hydroenvironmental effects of water extraction from the Sinaloa River aquifer. Universidad y Ciencia. 27, (3), 239, 2011.

12. ALIANZA PARA LA SUSTENTABILIDAD DEL NOROESTE COSTERO MEXICANO (ALCOSTA). Towards sustainable tourism on the northeast coast of Mexico. Mexico City. 2011.

13. INEGI. Mexican National Institute of Geography and Statistics 2011 Statistical yearbook by state. México, ISSN 1405-910X, D.F. 2011.

14. INEGI. (2010). Mexican National Institute of Geography and Statistics. Second Population and Housing Census 2005. Main results by locality www.inegi.org.mx/sistemas/ consulta resultados/iter2010.aspx?c $=27329 \& \mathrm{~s}=$ est .

15. LLANES C. O., NORZAGARAY C. M., MUÑOZ S. P., RUIZ G. R. Groundwater: Aquaculture alternative in northeast Mexico. Revista AquaTIC, Zaragoza Spain, $\mathrm{n}^{\circ}$ 38, pp. 10-20. 2013.

16. YUE S., WANG C.Y. Regional streamflow trend detection with consideration of both temporal and spatial correlation. Int. J. Climatol., 22, (8), 933, 2002. doi:10.1002/joc.781
17. KUMAR V., JAIN S.K. Trends in seasonal and annual rainfall and rainy days in Kashmir Valley in the last century. Quatern. Int., 212, (1), 64, 2010. doi:10.1016/j.quaint.2009.08.006

18. KAHYA E., KALAYCI S. Trend analysis of streamflow in Turkey. J. Hydrol., 289, (1-4), 128, 2004. doi:10.1016/j.jhydrol.2003.11.006

19. AKSU H., KOSCU S., SIMSEK O. Trend analysis of hydrometeorological parameters in climate regions of Turkey. In: State Hydraulic Works, http://balwois.com/balwois/administration/full_paper/ffp-1457.pdf. (Accessed: June 20, 2013). 2010.

20. YUNLING H., ZHANG Z. Climate Change from 1960 to 2000 in the Lancang River Valley, China. Mt. Res. Dev. 25, (4), 341, 2005.

21. BAUTISTA F.A., BAUTISTA HERNÁNDEZ D.A. ÁLVAREZ O., ANAYA ROMERO M., DE LA ROSA D. Software for identifying climate change trends at the local level: A case study in Yucatán, Mexico. Revista Chapingo. Serie de Ciencias Forestales y del Ambiente: 19, (1), 81, 2013.

22. VAN-BELLE G., HUGHES J. P. Nonparametric tests for trend in water quality. Water Resour. Res., 20, (1), 127, 1984.

23. FOOD \& AGRICULTURE ORGANIZATION OF THE UNITED NATIONS (FAO) -SECRETARIA DE AGRICULTURA, GANADERIA, DESARROLLO RURAL, PESCA Y ALIMENTACION (SAGARPA). Mexico: The agricultural sector and the challenge of climate change. Mexico City. 2012.

24. OJEDA BUSTAMANTE W., SIFUENTES IBARRA E., ÍNIIGUEZ COBARRUBIAS M., MONTERO MARTÍNEZ M.J. Impact of climate change on crop water needs and development. Agrociencia 45, 1, 2011.

25. SEMARNAT. Wetlands: First workshop on Ramsar sites in Baja California Sur. Mexico. 2011.

26. UN. Climate dynamics, trends and variability. Chile. 2011. 